\title{
Non-Neuronal Cells Exacerbate $\beta$-Amyloid Aggregation in the Aged Brain
}

\author{
(1) Grant T. Corbett and ${ }^{-}$Eric W. Buss \\ Graduate Program in Neuroscience, Department of Neurological Sciences, Rush University Medical Center, Chicago, Illinois 60612 \\ Review of Veeraraghavalu et al.
}

Genetic, molecular, pathological and biomarker studies suggest the amyloid precursor protein (APP) derivative $\beta$-amyloid $(\mathrm{A} \beta)$ plays an important role in the pathogenesis of Alzheimer's disease (AD). Generation of $40-42$ amino acid- $A \beta$ is contingent upon sequential proteolytic processing of APP by $\beta$-secretase- 1 (BACE1) and $\gamma$-secretase (Vassar et al., 1999). Cleavage of APP at one of two $\beta$-sites by BACE1 generates truncated C-terminal (C99 or C89) fragments that are subsequently cleaved by $\gamma$-secretase to release $\mathrm{A} \beta$ peptides. Though the majority of $A \beta$ peptides are 40 aa $\left(A \beta_{40}\right)$ in length, mutations in the genes encoding APP and the $\gamma$-secretase catalytic components presenilin-1 (PS1) and presenilin-2 increase production of 42-amino-acid species $\left(\mathrm{A} \beta_{42}\right)$, which are capable of rapid nucleation (Jarrett et al., 1993). These genetic mutations ultimately cause early onset, familial forms of AD (FAD) by elevating the $\mathrm{A} \beta_{42} / \mathrm{A} \beta_{40}$ ratio and exacerbating $\mathrm{A} \beta_{42}$ deposition in select forebrain

Received May 5, 2014; revised June 4, 2014; accepted June 6, 2014.

G.T.C. and E.W.B. are supported by a National Institutes on Aging Predoctoral training grant (5T32 AG000269, to Elliott J. Mufson). We thank Drs. Kalipada Pahan, Daniel A. Nicholson, Elliott J. Mufson, and Dustin R. Wakeman for their insightful discussions and helpful comments on this manuscript.

Correspondence should be addressed to either of the following: Grant $\mathrm{T}$. Corbett, Department of Neurological Sciences, Rush University Medical Center, 1735 West Harrison St, Suite 336, Chicago, IL 60612, E-mail: grant_corbett@rush.edu; or Eric W. Buss, Department of Neurological Sciences, Rush University Medical Center, 1750 West Harrison St, Suite 1474, Chicago, IL 60612, E-mail: eric_buss@rush.edu.

DOI:10.1523/JNEUROSCI.1825-14.2014

Copyright $\odot 2014$ the authors $\quad 0270-6474 / 14 / 349825-03 \$ 15.00 / 0$ regions, including the hippocampal complex and neocortex (Scheuner et al., 1996).

For over a quarter of a century, reports have indicated that non-neuronal cells express APP (Card et al., 1988) and secrete putative $\mathrm{A} \beta$ peptides (Busciglio et al., 1993), but it is widely believed that forebrain excitatory neurons produce the majority of $\mathrm{A} \beta$ in an activity-dependent manner (Kamenetz et al., 2003). In short, NMDAR-dependent neuronal activity is thought to increase APP endocytosis from the membrane via a clathrin-dependent mechanism, rendering it more susceptible to amyloidogenic processing within the endosomal system by BACE1. Intracellu$\operatorname{lar} \mathrm{A} \beta$ monomers and oligomers, the latter of which possess their own neurotoxic properties, are then released into the extracellular milieu (for review, see O'Brien and Wong, 2011), where they aggregate into larger fibrils and plaques and act as proinflammatory lesions, stimulating the activation of microglia and astrocytes. Reactive glial cells cluster around $\mathrm{A} \beta$ deposits, indicative of a phagocytic response that may have both beneficial and harmful effects on surrounding neurons. The deleterious effects of reactive glia on the $\mathrm{AD}$ brain are thought to stem from $\mathrm{A} \beta$ mediated release of proinflammatory molecules, including reactive oxygen species, interleukins, prostaglandins, cytokines, and complement factors. However, a recent report in The Journal of Neuroscience (Veeraraghavalu et al., 2014) suggests that astrocytes and microglia may play an additional role in $\mathrm{AD}$ pathobiology by contributing directly to cortical and hippocampal A $\beta$ load.

To examine glial-derived effects on overall brain $\mathrm{A} \beta$ load, Veeraraghavalu and colleagues (2014) used three previously characterized transgenic murine lines to exclusively direct production of human $\mathrm{A} \beta$ to non-neuronal cells (Fig. 1). In the first transgenic line, the ubiquitously expressed murine prion protein (PrP) promotes expression of FADlinked PS1 $\triangle E 9$ cDNA flanked by two loxP sites and a downstream copepod green fluorescent protein (cGFP) reporter (PrP.PS1 $\left.1 E 9^{\text {lox/lox }} . c G F P\right)$. The deletion of exon $9(\Delta E 9)$ from PS1 renders the protein resistant to endoproteolysis and alters the $\mathrm{A} \beta_{40} / \mathrm{A} \beta_{42}$ ratio. (Thinakaran et al., 1996). Crossing this line with mice expressing Cre recombinase driven by the excitatory neuron-specific promotor $\alpha \mathrm{CaMKII}$ ( $\alpha$ CaMKIICre) generates a second line of mice in which the mutant PS1 $1 \mathrm{E} 9$ is removed, but cGFP continues to be expressed in excitatory neurons located within the hippocampus, cortex, striatum, septum, and amygdala (Fig. 1). Thus, subsequent enhancement of $\mathrm{A} \beta$ production is limited to cells devoid of $\alpha$ CaMKII in these areas. However, it is important to note that interneurons, in addition to glia, may provide an alternative source of $A \beta$ in these mice.

In PrP.PS $1 \Delta E 9^{l o x} /$ lox.$c G F P$ mice, recombination-mediated reductions in PS1 $\Delta \mathrm{E} 9$ levels and subsequent cGFP expression occurred concomitantly, begin- 
ning at 6 weeks of age. Silencing and appearance of PS1 $1 \mathrm{E} 9$ and cGFP expression, respectively, were not observed at earlier ages because transcription of $\alpha$ CaMKII mRNA is developmentally restricted. Previous reports have indicated that expression of the excitatory neuronspecific, serine-threonine kinase $\alpha$ CaMKII increases approximately tenfold during the third week of life (Burgin et al., 1990) and stabilizes shortly thereafter. By 7 months of age, PS1 1 E9flox/ $\alpha$ CaMKIICre bigenic animals displayed a nearly $80 \%$ reduction in human PS1 $\triangle \mathrm{E} 9$ levels relative to agematched PS1 1 E9flox mice. Excision of the human PS1 $\triangle E 9$ cassette also elevated the accumulation of murine N-terminal fragmented PS1, indicative of successful recombination and recovery of endogenous PS1 expression. Moreover, PS1DE9 deletion was restricted to excitatory neurons as cGFP signal did not colocalize with the astrocyte-specific antigens glial fibrillary acidic protein and S100 calcium binding protein B (Veeraraghavalu and Sisodia, 2013).

A third transgenic strain used by Veeraraghavalu and colleagues (2014) was generated by breeding the PS1 $\Delta$ E9flox line with mice overexpressing APP mutations (K595N, M596L) linked to FAD (APPswe) (Veeraraghavalu et al., 2014). Bigenic APPswe/PS1DE9flox mice were then crossed with $\alpha C a M K I I C r e$ mice to generate trigenic animals expressing $P S 1 \triangle E 9$ in non-neuronal cells, cGFP in forebrain excitatory neurons, and $A P P$ swe ubiquitously (APPswe/PS1 $\Delta$ E9flox/ $\alpha$ CaMKIICre) (Fig. 1).

APPswe mice do not display plaque pathology until 18-20 months of age. However, Veeraraghavalu and colleagues (2014) show that global incorporation of mutated PS1 with APPswe (APPswel PS1 1 E9flox) increases $\mathrm{A} \beta_{42}$ production and exacerbates plaque deposition as early as 5-7 months of age. When mutated PS1 was restricted to non-neuronal cells (APPswe/PS1 1 E9flox/ $\alpha$ CaMKIICre), cortical and hippocampal $\mathrm{A} \beta$ load was negligible and indistinguishable from that in age-matched APPswe mice. In line with this finding, $A \beta$ load was significantly reduced in 8-9-month-old APPswel PS1 $\Delta$ E9flox/ $\alpha$ CaMKIICre mice relative to age-matched APPswe/PS1 1 E9flox mice. However, by age 10-12 months, APPswe/PS1 1 E9flox/ $\alpha$ CaMKIICre mice displayed robust increases in soluble and insoluble $\mathrm{AB}_{42}$ as well as plaque burden relative to age-matched APPswe mice. Therefore, 10-12-month-old APPswel PS1 1 E9flox/ $\alpha$ CaMKIICre mice were

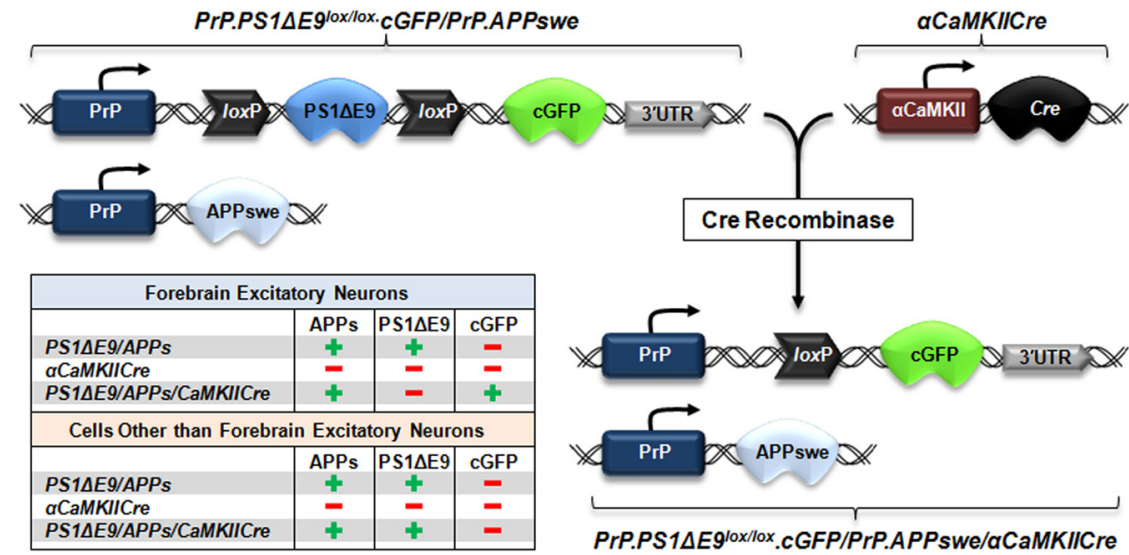

Figure 1. Illustration depicting generation of the APPSwe/PS1 1 E9flox/ $\alpha$ CaMKIICre transgenic line. Mice harboring mutated PS1 1 E9 CDNA flanked by two loxP sites and a downstream CGFP reporter were crossed with mice expressing $\alpha$ CaMKII-driven Cre recombinase. The table indicates cell-type-specific transgene expression in the models used by Veeraraghavalu and colleagues (2014). 3'-UTR, 3'-untranslated sequences of the PrP gene.

largely indistinguishable from APPswel PS1 $\Delta$ E9flox mice in terms of forebrain A $\beta$ load, despite the difference in the sources of $\mathrm{A} \beta 42$ production (i.e., non-neuronal versus neuronal).

In addition to the in vivo findings, Veeraraghavalu and colleagues (2014) found that astrocytes and microglia isolated from young APPswe/PS1 1 E9flox mice produced and secreted $A \beta$ in a $\gamma$-secretase-dependent manner. Although it appears that astrocytes, microglia, and neural progenitor cells harvested from APPswe/PS1 1 E9flox mice express notable levels of human APP and $A \beta_{40 / 42}$, how these levels compare to those produced by excitatory forebrain neurons remains unknown. A side-by-side comparison of the levels of neuron- and glia-derived $\mathrm{A} \beta$ species (monomer, dimer, trimer, oligomer, etc.) and other APP fragments would be beneficial in enhancing understanding of APP processing in non-neuronal cells.

Previous reports have shown that murine lines expressing the APP Swedish mutation alone ( $T$ g2576) exhibit progressive impairments in spatial reference memory beginning at 9 months of age, and coexpression of mutated PSEN1 with APPswe expedites these impairments by $\sim 3$ months. It would be interesting to ascertain whether excision of excitatory-neuronal PS1 $\Delta \mathrm{E}$ 9, which Veeraraghavalu and colleagues (2014) suggest accounts for $\sim 80 \%$ of brain PS1 $\Delta$ E9 at 7 months of age, is able to delay the appearance or slow the progression of behavioral impairments in APPswe/PS1 1 E9flox/ $\alpha$ CaMKIICre mice relative to age-matched $A P P$ swe/PS1 $\triangle E 9$ flox mice. Such data would support the development of specialized presenilin-1 inhibitors as potential therapeutic targets in AD. It is also possible that non-neuronal- derived $\mathrm{A} \beta$ species possess enhanced nucleation capacity, as amyloid burden rapidly increases between 8-9 and 10-12 months in APPswe/PS1DE9flox/ $\alpha C a M K I I C r e$ mice. If that were the case, perhaps APPswe/PS1 $\triangle E$ 9flox/ $\alpha$ CaMKIICre mice would show exacerbated cognitive impairments relative to APPswe/PS1 1 E9flox mice between the ages of 8 and 15 months. Such a finding could potentially implicate nonneuronal cells as the primary source of neurotoxic $\mathrm{A} \beta$ in the aged brain. Conversely, aggregation of glial-derived soluble $\mathrm{A} \beta$ oligomers and fibrils into plaques may provide a beneficial mechanism for sequestering more soluble forms of $\mathrm{A} \beta$ from the neuropil. Insertion of the $A P P$ swe and PS1 $1 E 9$ transgenes under the control of microglia- or astrocyte-specific promotors from birth would allow analysis of $\mathrm{A} \beta$ load independent of a contribution from excitatory neurons, ultimately leading to a greater understanding of AD gliobiology. Since interneuron-derived $\mathrm{A} \beta$ may constitute a portion of the total $A \beta$ load seen in their model, interneuron-specific promotion of the transgenes may also account for $A \beta$ production independent of excitatory neurons. Regardless, such ideas highlight several areas for future research based on the experiments of Veeraraghavalu et al. (2014).

Three important conclusions can be drawn from the data reported by Veeraraghavalu and colleagues (2014). First, excitatory neurons contribute greatly to early amyloid seeding in APPswe/PS1 1 E9flox mice, reinforcing the notion of activitydependent $\mathrm{A} \beta$ production. Second, nonneuronal cells possess the cellular machinery to synthesize and cleave APP and secrete $\mathrm{A} \beta_{40 / 42}$ in a manner similar to neurons, sup- 
porting the need for a greater understanding of glial function in AD. Third, cells other than excitatory forebrain neurons contribute greatly to hippocampal and cortical $\mathrm{A} \beta$ load in aged APPswe/PS1 1 E9flox/ $\alpha$ CaMKIICre mice, likely by constitutively synthesizing de novo $\mathrm{A} \beta$ peptides, which coalesce onto existing seeds or generate new seeds. In light of these findings, it is important to investigate the role of non-neuronal cells and interneurons in the production of small $A \beta$ peptides in both sporadic and familial AD.

\section{References}

Burgin KE, Waxham MN, Rickling S, Westgate SA, Mobley WC, Kelly PT (1990) In situ hybridization histochemistry of $\mathrm{Ca} 2+/$ calmodulindependent protein kinase in developing rat brain. J Neurosci 10:1788-1798. Medline

Busciglio J, Gabuzda DH, Matsudaira P, Yankner BA (1993) Generation of beta-amyloid in the secretory pathway in neuronal and nonneuronal cells. Proc Natl Acad Sci U S A 90: 2092-2096. CrossRef Medline

Card JP, Meade RP, Davis LG (1988) Immuno- cytochemical localization of the precursor protein for beta-amyloid in the rat central nervous system. Neuron 1:835-846. CrossRef Medline

Jarrett JT, Berger EP, Lansbury PT Jr (1993) The C-terminus of the beta protein is critical in amyloidogenesis. Ann N Y Acad Sci 695:144148. CrossRef Medline

Kamenetz F, Tomita T, Hsieh H, Seabrook G, Borchelt D, Iwatsubo T, Sisodia S, Malinow R (2003) APP processing and synaptic function. Neuron 37:925-937. CrossRef Medline

O'Brien RJ, Wong PC (2011) Amyloid precursor protein processing and Alzheimer's disease. Annu Rev Neurosci 34:185-204. CrossRef Medline

Scheuner D, Eckman C, Jensen M, Song X, Citron M, Suzuki N, Bird TD, Hardy J, Hutton M, Kukull W, Larson E, Levy-Lahad E, Viitanen M, Peskind E, Poorkaj P, Schellenberg G, Tanzi R, Wasco W, Lannfelt L, Selkoe D, Younkin S (1996) Secreted amyloid betaprotein similar to that in the senile plaques of Alzheimer's disease is increased in vivo by the presenilin 1 and 2 and APP mutations linked to familial Alzheimer's disease. Nat Med 2:864-870. CrossRef Medline

Thinakaran G, Borchelt DR, Lee MK, Slunt HH,
Spitzer L, Kim G, Ratovitsky T, Davenport F, Nordstedt C, Seeger M, Hardy J, Levey AI, Gandy SE, Jenkins NA, Copeland NG, Price DL, Sisodia SS (1996) Endoproteolysis of presenilin 1 and accumulation of processed derivatives in vivo. Neuron 17:181-190. CrossRef Medline

Vassar R, Bennett BD, Babu-Khan S, Kahn S, Mendiaz EA, Denis P, Teplow DB, Ross S, Amarante P, Loeloff R, Luo Y, Fisher S, Fuller J, Edenson S, Lile J, Jarosinski MA, Biere AL, Curran E, Burgess T, Louis JC, et al. (1999) Beta-secretase cleavage of Alzheimer's amyloid precursor protein by the transmembrane aspartic protease BACE. Science 286:735-741. CrossRef Medline

Veeraraghavalu K, Sisodia SS (2013) Mutant presenilin 1 expression in excitatory neurons impairs enrichment-mediated phenotypes of adult hippocampal progenitor cells. Proc Natl Acad Sci U S A 110:9148-9153. CrossRef Medline

Veeraraghavalu K, Zhang C, Zhang X, Tanzi RE, Sisodia SS (2014) Age-dependent, non-cellautonomous deposition of amyloid from synthesis of beta-amyloid by cells other than excitatory neurons. J Neurosci 34:3668-3673. CrossRef Medline 